\title{
Renal injury in female dogs with pyometra
}

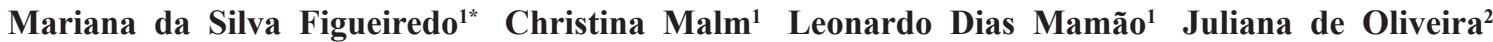 \\ Júlio César Cambraia Veado ${ }^{1}$ Mariana Pádua Costa ${ }^{1}$ Pâmela Cristina Lopes Gurgel Valente ${ }^{1}$ \\ Rodrigo dos Santos Horta ${ }^{1}$ Marina Lopes Castro ${ }^{1}$ Aline Gomes de Castro ${ }^{1}$ Leila Sbaraini $^{1}$ \\ Eliana Matias de Souza ${ }^{1}$
}

\author{
${ }^{1}$ Escola de Veterinária, Universidade Federal de Minas Gerais (UFMG), Campus Pampulha, 31270-901, CP 567, Belo Horizonte, MG, Brasil. \\ E-mail: marysfigueiredo@gmail.com. .Corresponding author. \\ ${ }^{2}$ Universidade Federal Fluminense (UFF), Polo Universitário de Nova Friburgo, Nova Friburgo, RJ, Brasil.
}

\begin{abstract}
Pyometra is a common disease in intact female dogs and can cause glomerulopathy and tubular injury. This study aimed to evaluate kidney injury in female dogs with pyometra, as well as progression of the injury during treatment and the markers of this condition. This study analyzed 20 intact female dogs with both clinical and sonographic diagnosis of pyometra. Dogs were treated with intravenous fluids and antibiotics, and an ovariohysterectomy was performed. The following parameters were assessed at eight separate time points: blood pressure; serum creatinine, phosphorus, and urea levels; urinalysis and urinary biochemical parameters [urinary gamma-glutamyl transferase $(u G G T)$ and urinary protein-to-creatinine ratio (UPCR)]; glomerular filtration rate (GFR); and urine output. All dogs showed some degree of kidney injury at the time of pyometra diagnosis. This was transient in most animals, resolving with treatment of the pyometra. Measurement of $u G G T$ and UPCR identified renal parenchymal injury, helping to determine the prognosis of the animals analyzed in the present study. Key words: kidney disease, kidney function, urinary GGT, urinary protein-to-creatinine ratio, glomerular filtration rate.
\end{abstract}

Injúria renal em cadelas com piometra

RESUMO: A piometra é afecção frequente em cadelas e pode causar glomerulopatias e lesões tubulares. O presente estudo objetivou avaliar injúria renal em cadelas com piometra, sua progressão ao longo do tratamento e o uso de marcadores dessa alteração. Participaram 20 cadelas com diagnóstico clínico e ultrassonográfico de piometra, submetidas à fluidoterapia, antibioticoterapia e ovariohisterectomia. Foram avaliados pressão arterial, concentração sérica de creatinina, fósforo e ureia; urinálise e bioquímica urinária (gama-glutamiltransferase urinária e razão proteína/creatinina urinárias), taxa de filtração glomerular e débito urinário, em oito tempos. Todas as cadelas apresentaram algum grau de injúria renal no momento do diagnóstico da piometra, sendo transitória na maioria dos animais após o tratamento. O uso de marcadores de injúria renal identificou lesão de parênquima renal, contribuindo com o prognóstico dos animais estudados.

Palavras-chave: cadela, doença renal, função renal, piometra.

\section{INTRODUCTION}

Female dogs with pyometra may also manifest decreased renal perfusion, immunemediated glomerulonephritis, low ability for urinary concentration, interstitial tubular disease and/or decreased GFR (STONE et al., 1988; HEIENE et al., 2001; MASTROCINQUE, 2002; OLIVEIRA, 2007; FOSSUM, 2008; CHEW et al., 2011). These changes are caused by injuries to different parts of the kidney, resulting in varying degrees of renal impairment. The evolution of these changes is gradual and can result in kidney failure.
Renal excretory function is commonly evaluated by serum creatinine concentration. This value increases when $66-75 \%$ of the nephrons are compromised, complicating treatment and recovery of the patient. Kidney failure may follow and the mortality rate is reported to be $50 \%$ (SANTOS, 2014). Therefore, analyses that identify early kidney injuries are important to improve both clinical management of the disease and the prognosis for survival (CHEW et al., 2011; STOCKHAM \& SCOTT, 2011; FREITAS et al., 2014).

Measurement of urine protein assesses the integrity of the glomerular endothelium and it can be evaluated by routine urine examination 
or, more precisely, by the UPCR. Proteinuria, or more specifically albuminuria, indicates glomerulonephropathy. Tubular cell lesions can be identified by measuring uGGT. Decreased GFR is another indicator of impending renal failure. GFR is directly related to the number of functional nephrons and is the gold standard for assessing kidney function. Serum phosphorus concentration is a sensitive marker of excretory function and is directly related to GFR. An elevation in serum phosphorus concentration precedes azotemia with several kidney injuries (GRECO et al., 1985; ROCHA \& VEADO, 2005; CHEW et al., 2011; NABITY, 2011; HARLEY \& LANGSTON, 2012; FREITAS et al., 2014).

Both pyometra and surgical and/or anesthetic complications associated with its treatment can cause kidney injury. A late diagnosis of pyometra, when kidney failure hasalready occurred, may result in irreversible damage to the kidneys (FOSSUM, 2008). This study aimed to evaluate kidney injury at the time of diagnosis of pyometra as well as progression of kidney injury during treatment for pyometra.

\section{MATERIALS AND METHODS}

The present study evaluated 20 intact female dogs of varying breeds. All animals were between 6 and 15 years of age and had been diagnosed with pyometra. Animals were treated at the Veterinary Hospital of the Universidade Federal de Minas Gerais (UFMG), Brazil, between May and December 2012. Treatment consisted of ovariohysterectomy and antibiotics, with all animals receiving IV fluid therapy (Lactated Ringer's solution at $20 \mathrm{~mL} \mathrm{~kg}^{-1} \mathrm{~h}^{-1}$ for fluid replacement over 3 to $4 \mathrm{~h}$ and then $60 \mathrm{~mL} \mathrm{~kg}^{-1} \mathrm{day}^{-1}$ for maintenance) beginning immediately upon diagnosis. Parenteral fluid therapy was maintained for up to $48 \mathrm{~h}$ after surgery. The animals were medicated with amoxicillin-potassium clavulanate (20 $\mathrm{mg} \mathrm{kg}^{-1}$ BID x 10 days). Ovariohysterectomy was performed following clinical stabilization.

The anesthetic protocol consisted of premedication with tramadol hydrochloride $\left(4 \mathrm{mg} \mathrm{kg}^{-1}\right.$ IV) followed by induction with $1 \%$ propofol $(5 \mathrm{mg}$ $\mathrm{kg}^{-1} \mathrm{IV}$ ). Isoflurane in $\mathrm{O}_{2}$ was used for maintenance. Postoperative analgesia was provided by tramadol hydrochloride ( $3 \mathrm{mg} \mathrm{kg}^{-1}$ IV TID x 3 days).

Physical examinations and laboratory tests were performed at eight time points: T0 (diagnosis and hospitalization), T1 (period after fluid replacement), T2 (1-2h of fluid therapy for maintenance after T1), T3 (12h after surgery), T4 (24h after surgery), T5 (48h after surgery), T6 (10 days after surgery), and T7 (60 days after surgery).
Diagnostic tests performed included oscillometric blood pressure measurement (CONTEC 08A Veterinary Digital Blood Pressure \& Heart Beat Monitor \& $\mathrm{SpO}_{2}$ Monitor, Contec, China); serum creatinine, phosphorous, and urea measurements; urinalysis and urine biochemistry (uGGT, UPCR) by enzymatic, kinetic and colorimetric methods on Cobas Mira Plus $\left(\right.$ Roche $^{\circledR}$ ) automated spectrophotometer according to reagent kit specifications (Synermed ${ }^{\circledR}$ ); urine output (UO) and endogenous creatinine clearance (GFR). UO and GFR were calculated using a urethral catheter connected to a closed urinary drainage system and measured from T4 due to the minimum amount of time necessary for the calculation (24h). The following formulas were used: $\mathrm{UO}=$ urine volume $(\mathrm{mL})$ weight ${ }^{-1}(\mathrm{~kg}) 24 \mathrm{~h}^{-1}$ and GFR $=$ [urine creatinine $\left(\mathrm{mg} \mathrm{dL}^{-1}\right) \mathrm{x}$ urine volume $\left.(\mathrm{mL})\right] /$ [serum creatinine $\left(\mathrm{mg} \mathrm{dL}^{-1}\right) \mathrm{x}$ weight $(\mathrm{kg}) \mathrm{x}$ time (min)]. Systolic blood pressure (SBP) $>150 \mathrm{mmHg}$ was consistent with hypertension.

Statistical analysis was performed using a completely randomized design and the differences were considered to be significant when $\mathrm{P}<0.05$. Parametric data were tested for normality (Kolmogorov-Smirnov test) and homoscedasticity and subjected to analysis of variance. Either Duncan's test or the Kruskal-Wallis test was used to compare different time points. Dispersion frequency was evaluated by the Fisher's exact test and interactions were evaluated by Spearman's correlation for data not normally distributed (creatinine, phosphorus, and GFR; SBP and UPCR; UPCR and leukocyturia, pyuria, bacteriuria, and uGGT; uGGT and renal epithelial (kidney cells and pelvis cells) cells in the urinary sediment).

\section{RESULTS AND DISCUSSION}

Varying degrees of azotemia (increased urea and/or creatinine) were observed among the female dogs at the different time points as shown in table 1. At T0, fewer of the dogs in this study were azotemic than has been previously reported. STONE et al. (1988) analyzed 27 female dogs with pyometra and found $26 \%$ of them to be azotemic at the time of diagnosis. ALBUQUERQUE (2010) analyzed 170 female dogs with pyometra reported that $17.6 \%$ had increased creatinine measurements and $34.1 \%$ had increased urea measurements at the time of diagnosis. In analyzing 20 female dogs with pyometra, EVANGELISTA et al. (2010) reported that $30 \%$ of them had increased creatinine measurements and $75 \%$ had increased urea measurements whereas MIRA (2010), in analyzing the same number of affected dogs, reported that $30 \%$ 
Table 1 - Mean, standard deviation, and relative frequency of elevated systolic blood pressure and serum creatinine, urea, and phosphorus at different time points for 20 female dogs with pyometra.

\begin{tabular}{|c|c|c|c|c|c|c|c|c|}
\hline & $\mathrm{M}$ and $\mathrm{SD} \mathrm{mmHg}$ & $\begin{array}{c}\mathrm{SBP}>150 \\
\mathrm{mmHg}(\%)\end{array}$ & $\begin{array}{l}\mathrm{M} \text { and SD } \\
\left(\mathrm{mg} \mathrm{dL}^{-1}\right)\end{array}$ & $\begin{array}{c}\text { Creatinine }>1.5 \\
\mathrm{mg} \mathrm{dL}^{-1}(\%)\end{array}$ & $\begin{array}{l}\text { M and SD } \\
(\mathrm{mg} / \mathrm{dL})\end{array}$ & $\begin{array}{c}\text { urea }>56 \mathrm{mg} \\
\mathrm{dL}^{-1}(\%)\end{array}$ & $\begin{array}{l}\text { M and SD } \\
\left(\mu \mathrm{g} \mathrm{dL}^{-1}\right)\end{array}$ & $\begin{array}{c}\text { Phosphorus }>5.3 \\
\operatorname{Mg~dL}^{-1}(\%)\end{array}$ \\
\hline T0 & 145.10 a (32.48) & 40 & 1.40 a $(0.89)$ & 11 & $\begin{array}{l}41.27 b \\
(24.06)\end{array}$ & 17 & $\begin{array}{c}6.39 \mathrm{ab} \\
(4.21)\end{array}$ & 42 \\
\hline $\mathrm{T} 1$ & $152.07 \mathrm{a}(31.18)$ & 36 & $1.40 \mathrm{a}(1.01)$ & 15 & $\begin{array}{c}37.92 \mathrm{ab} \\
(25.62)\end{array}$ & 15 & $\begin{array}{l}6.82 \mathrm{bc} \\
(4.40)\end{array}$ & 64 \\
\hline $\mathrm{T} 2$ & 146.55 a (28.95) & 40 & $1.38 \mathrm{a}(0.90)$ & 26 & $\begin{array}{c}34.97 \mathrm{ab} \\
(24.41)\end{array}$ & 16 & $\begin{array}{c}5.78 \mathrm{ab} \\
(3.38)\end{array}$ & 45 \\
\hline $\mathrm{T} 3$ & 156.55 a (35.37) & 55 & $1.30 \mathrm{a}(0.67)$ & 20 & $\begin{array}{l}29.61 \mathrm{a} \\
(25.50)\end{array}$ & 10 & $\begin{array}{l}4.86 \mathrm{a} \\
(2.45)\end{array}$ & 30 \\
\hline $\mathrm{T} 4$ & 137.70 a (23.90) & 35 & $1.28 \mathrm{a}(0.57)$ & 25 & $\begin{array}{l}28.26 \mathrm{a} \\
(19.75)\end{array}$ & 10 & $\begin{array}{c}4.98 \mathrm{ab} \\
(1.51)\end{array}$ & 30 \\
\hline T5 & 142.05 a (31.93) & 40 & $1.12 \mathrm{a}(0.32)$ & 10 & $\begin{array}{c}31.49 \mathrm{ab} \\
(16.16)\end{array}$ & 5 & $\begin{array}{l}5.61 \mathrm{bc} \\
(0.96)\end{array}$ & 68 \\
\hline T6 & 139.25 a (28.62) & 45 & $1.12 \mathrm{a}(0.47)$ & 15 & $\begin{array}{l}36.48 \mathrm{~b} \\
(15.63)\end{array}$ & 10 & $\begin{array}{l}6.78 \mathrm{c} \\
(1.71)\end{array}$ & 70 \\
\hline T7 & 139.53 a (23.75) & 29 & $1.33 \mathrm{a}(0.46)$ & 33 & $\begin{array}{l}38.69 \mathrm{~b} \\
(12.02)\end{array}$ & 7 & $\begin{array}{l}5.45 \mathrm{ab} \\
(2.54)\end{array}$ & 40 \\
\hline
\end{tabular}

Values followed by different letters (column) were significantly different $(\mathrm{P}<0.05)$. Time points: T0 (diagnosis and hospitalization), T1 (period after fluid replacement), T2 (1-2h of fluid therapy for maintenance after T1), T3 (12h after surgery), T4 (24h after surgery), T5 (48h after surgery), T6 (10 days after surgery), and T7 (60 days after surgery). M = Mean; SD = standard deviation.

of them had increased creatinine measurements. Preexisting kidney damage and time elapsed between the development of pyometra and treatment start are relevant factors for this variation, but it is difficult to ascertain this information in the clinical setting.

The presence of azotemia in the animals in this study at T6 and T7 suggests either preexisting kidney injury or the development of chronic kidney disease secondary to a major insult (pyometra). These two conditions could not be distinguished because neither ultrasonography nor kidney biopsy was performed in the present study. EVANGELISTA et al. (2010) also reported increased creatinine measurements in female dogs 10 days after ovariohysterectomy were performed as treatment for pyometra, including those without azotemia at the time of diagnosis. This points out the importance of postoperative evaluation of kidney function in dogs treated for pyometra.

Regarding serum phosphorus levels, some of the animals in the present study had elevated measurements at all time points, including T6 and T7 (Table 1). At T0, the mean values were similar to those reported by YU (2012), who studied 49 female dogs with pyometra (phosphorus $6.3 \pm 0.6 \mu \mathrm{g}$ $\left.\mathrm{dL}^{-1}\right)$. Phosphorus levels were greater than those reported by ZARAGOZA et al. (2004) at this same time point (phosphorus $5.05 \mu \mathrm{g} \mathrm{dL}^{-1}$ ), who studied 15 female dogs with the same condition. The evaluation of serum phosphorus levels at different time points revealed that eight of the animals in this study (40\%) had hyperphosphatemia without azotemia, and subsequently showed increased creatinine measurements; however, this was not statistically significant $(\mathrm{P}=0.05)$. Hyperphosphatemia may result from reduced renal excretion secondary to decreased GFR. This often precedes azotemia (ROCHA \& VEADO, 2005; CHEW et. al., 2011). However, a statistically significant correlation between phosphorus level and GFR was not observed $(\mathrm{P}=0.17)$. A high percentage of the animals were hyperphosphatemic at T6; although, there was no reduction in GFR. Uncommonly, other factors such as diet, acidosis, and hormonal changes can interfere with serum phosphorus levels. These factors were not evaluated in the present study.

Hypertension was noted at all time points (Table 1) and no correlation was observed between systolic blood pressure and proteinuria $(\mathrm{P}=0.54)$. Of the four animals that were persistently hypertensive at more than five time points, only two (50\%) also had proteinuria at T6 and T7. FINCO (2004) and STEPIEN \& ELLIOTT (2007) reported that persistent hypertension was always associated with progressive kidney damage; however, this was only observed in some of the animals in the present study.

Regarding urine specific gravity (Table 2), among the five animals noted to be azotemic at T0, 3 $(60 \%)$ were also isosthenuric. This finding indicates the 
existence of a renal or prerenal disorder resulting in low ability for urinary concentration. This may be due to endotoxemia which is liable to occur with pyometra. The kidneys of patients with prerenal azotemia are commonly functional and should respond to hypoperfusion by developing hypersthenuria (MASTROCINQUE, 2002; OLIVEIRA, 2007; FOSSUM, 2008). This was not observed in the animals in this study.

Isosthenuria can occur in animals subjected to rehydration procedures and in animals whose kidneys have lost the ability to concentrate urine (STOCKHAM \& SCOTT, 2011). Of the four isosthenuric animals at T0, two (50\%) demonstrated polydipsia, explaining the decrease in urine concentration noted. The primary differential for the remaining two animals is chronic kidney injury because polydipsia was not observed and they had not yet received intravenous fluid therapy. A high frequency of animals with reduced GFR, isosthenuria, and polyuria was evident at T4 and T5 (Tables 2 and 3), suggesting an inability by the kidneys to concentrate urine caused in many of the dogs by pyometra.

Hyposthenuria indicates that the renal tubules maintain the ability to dilute urine. Hyposthenuria is not expected to be reported in dehydrated animals. However, it was observed in one dehydrated dog, which may have resulted from desensitization to antidiuretic hormone (ADH or vasopressin) in the renal tubules caused by bacterial endotoxins. This characterizes nephrogenic diabetes insipidus (MASTROCINQUE, 2002; FOSSUM, 2008). Hyposthenuria observed at T1 was probably due to fluid therapy.
An improvement in GFR, resolution of isosthenuria, and decreased urine output were observed in animals at T6 and T7 (Tables 2 and 3), indicating restoration of urine concentrating ability. The resolution of isosthenuria observed $12 \mathrm{~h}$ after surgery in the present study occurred earlier than that reported by MASTROCINQUE (2002), indicating the effectiveness of treatments performed in this study.

Animals with reduced GFR were observed at all time points. UO was higher during fluid therapy, and polyuria or oliguria were identified at all time points (Table 3). HEIENE et al. (2001) evaluated 55 female dogs with pyometra and reported lower average GFR's in late assessments as compared to values obtained $24 \mathrm{~h}$ after ovariohysterectomy. This is not in agreement with the present study. The predominance of animals with reduced GFR at T4 and T5 was also observed by VERSTEGEN et al. (2008), who stated that even among non-azotemic and rehydrated female dogs with pyometra, GFR is often decreased. This suggested that other factors, such as glomerulonephritis, can alter renal perfusion. An improvement in GFR was observed at $\mathrm{T} 6$ and T7, suggesting restoration of kidney function in most animals although, the presence of any animals with changes in this parameter indicated the need for long term monitoring and treatment after surgery. Among the animals with reduced GFR at T6 and/or T7, only $50 \%$ showed increased phosphorus levels and only $25 \%$ showed increased creatinine levels, demonstrating greater sensitivity of GFR in detecting changes in kidney excretory function (CHEW et al., 2011).

Regarding proteinuria, $65 \%$ of the dogs possessed an increased UPCR at T0. The frequency remained high until T5, then decreased at T6 and T7

Table 2 - Mean, standard deviation, and relative frequency of urine concentrating ability at various time points for 20 female dogs with pyometra.

\begin{tabular}{|c|c|c|c|c|c|}
\hline & $\begin{array}{c}\text { Mean and } \\
\text { standand deviation }\end{array}$ & $\begin{array}{l}\text { Frequency of Hyposthenuria } \\
\quad(\text { Density }<1.008)(\%)\end{array}$ & $\begin{array}{l}\text { Frequency of Isosthenuria } \\
\text { (Density 1.008-1.014) (\%) }\end{array}$ & $\begin{array}{c}\text { Frequency of } \\
\text { animals (Density } \\
1.015-1.045)(\%)\end{array}$ & $\begin{array}{c}\text { Frequency of } \\
\text { Hypersthenuria } \\
(\text { Density }>1.045)(\%)\end{array}$ \\
\hline T0 & $1.027 \mathrm{~cd}(0.017)$ & 5 & 21 & 63 & 11 \\
\hline $\mathrm{T} 1$ & $1.014 \mathrm{a}(0.009)$ & 21 & 50 & 29 & 0 \\
\hline $\mathrm{T} 2$ & $1.016 \mathrm{ab}(0.011)$ & 10 & 60 & 25 & 5 \\
\hline $\mathrm{T} 3$ & $1.021 \mathrm{bc}(0.011)$ & 5 & 15 & 75 & 5 \\
\hline $\mathrm{T} 4$ & $1.017 \mathrm{abc}(0.008)$ & 5 & 40 & 55 & 0 \\
\hline T5 & $1.018 \mathrm{abc}(0.008)$ & 0 & 50 & 50 & 0 \\
\hline T6 & $1.033 \mathrm{de}(0.012)$ & 5 & 0 & 90 & 5 \\
\hline $\mathrm{T} 7$ & 1.043 e $(0.020)$ & 0 & 0 & 59 & 41 \\
\hline
\end{tabular}

Values followed by different letters (column) were significantly different $(\mathrm{P}<0.05)$. Time points: T0 (diagnosis and hospitalization), T1 (period after fluid replacement), T2 (1-2h of fluid therapy for maintenance after T1), T3 (12h after surgery), T4 (24h after surgery), T5 (48h after surgery), T6 (10 days after surgery), and T7 (60 days after surgery). 
Table 3 - Mean, standard deviation, and relative frequency of increased UPCR, increased GGT, decreased GFR and decreased UO at different time points for 20 female dogs with pyometra.

\begin{tabular}{|c|c|c|c|c|c|c|c|c|c|}
\hline & $\begin{array}{l}\mathrm{M} \text { and } \\
\mathrm{SD}\end{array}$ & $\begin{array}{l}\text { UPCR }> \\
0.2(\%)\end{array}$ & $\begin{array}{l}\mathrm{M} \text { and SD } \\
\left(\mathrm{UI} \mathrm{L}^{-1}\right)\end{array}$ & $\begin{array}{l}\text { GGT }>92 \\
\text { UI/L }(\%)\end{array}$ & $\begin{array}{l}\mathrm{M} \text { and SD mL } \\
\mathrm{kg}^{-1} \mathrm{~min}^{-1}\end{array}$ & $\begin{array}{c}\mathrm{GFR}<2 \mathrm{~mL} \\
\mathrm{~kg}^{-1} \min ^{-1}(\%)\end{array}$ & $\begin{array}{l}\text { M and SD } \\
\mathrm{mL} \mathrm{kg}^{-1} \mathrm{~h}^{-1}\end{array}$ & $\begin{array}{c}\text { Oliguria UO }<1 \mathrm{~mL} \\
\mathrm{~kg}^{-1} \mathrm{~h}^{-1}(\%)\end{array}$ & $\begin{array}{c}\text { Polyuria UO }>2 \mathrm{~mL} \\
\mathrm{~kg}^{-1} \mathrm{~h}^{-1}(\%)\end{array}$ \\
\hline T0 & $\begin{array}{r}0.76 \mathrm{bc} \\
(0.81)\end{array}$ & 65 & $\begin{array}{l}339.87 \mathrm{c} \\
(531.43)\end{array}$ & 70 & NM & NM & $\mathrm{NM}$ & NM & NM \\
\hline $\mathrm{T} 1$ & $\begin{array}{l}1.21 \mathrm{c} \\
(0.89)\end{array}$ & 85 & $\begin{array}{c}153.81 \mathrm{ab} \\
(244.94)\end{array}$ & 39 & NM & NM & NM & NM & NM \\
\hline $\mathrm{T} 2$ & $\begin{array}{r}0.83 \mathrm{bc} \\
(0.51)\end{array}$ & 90 & $\begin{array}{c}167.12 \mathrm{abc} \\
(318.20)\end{array}$ & 55 & NM & NM & $\mathrm{NM}$ & NM & NM \\
\hline T3 & $\begin{array}{r}0.70 \mathrm{bc} \\
(0.41)\end{array}$ & 95 & $\begin{array}{l}151.34 \mathrm{bc} \\
(138.67)\end{array}$ & 50 & NM & NM & NM & NM & NM \\
\hline $\mathrm{T} 4$ & $\begin{array}{l}0.54 \mathrm{~b} \\
(0.44)\end{array}$ & 80 & $\begin{array}{c}91.06 \mathrm{ab} \\
(99.53)\end{array}$ & 32 & $2.33 \mathrm{ab}(1.67)$ & 55 & $\begin{array}{l}1.78 \mathrm{bc} \\
(1.07)\end{array}$ & 20 & 40 \\
\hline T5 & $\begin{array}{r}0.61 b c \\
(0.47)\end{array}$ & 90 & $\begin{array}{c}93.24 \mathrm{ab} \\
(77.87)\end{array}$ & 42 & $2.04 \mathrm{a}(1.40)$ & 63 & $\begin{array}{l}1.87 \mathrm{c} \\
(1.08)\end{array}$ & 25 & 35 \\
\hline T6 & $\begin{array}{l}0.23 \mathrm{a} \\
(0.28)\end{array}$ & 32 & $\begin{array}{l}54.55 \mathrm{a} \\
(33.48)\end{array}$ & 20 & $2.55 \mathrm{~b}(1.33)$ & 26 & $\begin{array}{c}1.12 \mathrm{ab} \\
(0.58)\end{array}$ & 45 & 5 \\
\hline $\mathrm{T} 7$ & $\begin{array}{l}0.14 \mathrm{a} \\
(0.19)\end{array}$ & 21 & $\begin{array}{l}50.41 \mathrm{a} \\
(23.18)\end{array}$ & 8 & $2.66 \mathrm{ab}(1.23)$ & 42 & $\begin{array}{l}0.81 \mathrm{a} \\
(0.33)\end{array}$ & 76 & 0 \\
\hline
\end{tabular}

Values followed by different letters (column) were significantly different $(\mathrm{P}<0.05)$. Time points: T0 (diagnosis and hospitalization), $\mathrm{T} 1$ (period after fluid replacement), T2 (1-2h of fluid therapy for maintenance after T1), T3 (12h after surgery), T4 (24h after surgery), T5 (48h after surgery), T6 (10 days after surgery), and T7 (60 days after surgery). M = Mean; SD = Standard Deviation; NM = Not Measured.

(Table 3). uGGT was also elevated at T0, and then decreased in the subsequent evaluations (Table 3). ZARAGOZA et al. (2004) studied 15 female dogs with pyometra and observed a higher mean UPCR (1.13) and a higher frequency of animals with proteinuria $(93 \%)$ than was observed in the present study. At $\mathrm{T} 0$, the frequency of proteinuria was higher than the frequency of azotemia, which was also reported by MADDENS et al. (2011). This demonstrated the importance of conducting tests that can identify early kidney injury, as it is often a silent condition. A higher frequency of animals with proteinuria was observed at early time points, suggesting glomerular damage (immune-mediated glomerulonephritis), which is often transitory and can be reversed after removal of the diseased uterus (MASTROCINQUE, 2002; OLIVEIRA, 2007; FOSSUM, 2008). In the present study, there was no correlation between increased UPCR and the presence of urinary sediment components (leukocytes, erythrocytes, and bacteria). This suggested that increased UPCR indicates proteinuria of renal origin that is little influenced by inflammation and infection of other segments of the urinary tract (ELLIOTT \& GRAUER, 2007; CHEW et al., 2011; ROSA et al., 2016).

Animals with persistent proteinuria may develop severe kidney damage according to HEIENE et al. (2007). Some animals continued to have proteinuria
60 days after surgery (Table 3), demonstrating that kidney function evaluation remains necessary in the late postoperative period.

Regarding uGGT, the frequency of enzymuria observed in this study at T0 (70\%) was higher than that reported by DE SCHEPPER et al. (1989) (49\% of 75 female dogs). In addition, at T0, the number of animals with enzymuria was higher than the number of animals with increased urea and creatinine, suggesting that the female dogs developed tubular injury before manifesting azotemia. This supports an early diagnosis of kidney injury (ROCHA \& VEADO, 2005). Urinary GGT is primarily located in the brush border of proximal tubule cells and is released when the cellular membrane is damaged. Serum GGT is too large of a molecule to cross the selective wall of the glomerulus and; therefore, increased levels of uGGT suggested a renal tubular cell origin. In the present study, uGGT was significantly correlated with increased UPCR ( $\mathrm{P}=0.01 ; \mathrm{r}=0.22)$, suggesting tubular damage caused by albuminuria (GRAUER, 2005). In addition, the significant correlations between uGGT and the presence of renal epithelial cells (kidney cells) $(\mathrm{P}<0.01 ; \mathrm{r}=0.26)$ and granular casts $(\mathrm{P}<0.01$; $\mathrm{r}=0.25$ ) in the urine confirmed tubular injury.

Granular casts were the most common type reported in the present study (Table 4). Granular casts are formed in the renal tubules and the presence 
Table 4 - Relative frequency (\%) of animals with an increased number of casts, cells, and bacteria in the urine sediment at different time points for 20 female dogs with pyometra.

\begin{tabular}{|c|c|c|c|c|c|c|c|c|}
\hline & T0 & $\mathrm{T} 1$ & $\mathrm{~T} 2$ & $\mathrm{~T} 3$ & $\mathrm{~T} 4$ & T5 & T6 & $\mathrm{T} 7$ \\
\hline Hyaline Casts ( $>2 /$ field) & 20 & 0 & 0 & 0 & 0 & 0 & 5 & $12 ., 5$ \\
\hline Granular Casts (>2/field) & 55 & 31 & 47 & 53 & 50 & 75 & 65 & 62.5 \\
\hline Cellular Casts ( $>0 /$ field) & 0 & 0 & 0 & 0 & 10 & 5 & 0 & 0 \\
\hline Mixed Casts ( $>0 /$ field $)$ & 5 & 0 & 0 & 0 & 0 & 5 & 0 & 0 \\
\hline Kidney cells $(>0$ /field) & 40 & 31 & 37 & 42 & 15 & 20 & 35 & 12 \\
\hline Pelvis cells ( $>0$ / field) & 25 & 8 & 11 & 21 & 5 & 5 & 5 & 24 \\
\hline Vesicle Cells ( $>0$ / field) & 75 & 39 & 63 & 63 & 50 & 65 & 70 & 75 \\
\hline Urethral Cells ( $>0$ / field $)$ & 75 & 62 & 58 & 58 & 30 & 50 & 70 & 88 \\
\hline Erythrocytes ( $>5 /$ field) & 75 & 100 & 79 & 100 & 95 & 95 & 80 & 53 \\
\hline Leucocytes ( $>5 /$ field $)$ & 75 & 85 & 79 & 85 & 75 & 90 & 70 & 71 \\
\hline Bacteria (>0/ field) & 100 & 85 & 84 & 90 & 95 & 75 & 95 & 94 \\
\hline
\end{tabular}

Time points: T0 (diagnosis and hospitalization), T1 (period after fluid replacement), T2 (1-2h of fluid therapy for maintenance after T1), T3 (12h after surgery), T4 (24h after surgery), T5 (48h after surgery), T6 (10 days after surgery), and T7 (60 days after surgery).

of increased amounts indicates tubular injury (STOCKHAM \& SCOTT, 2011), which was confirmed in the present study by the correlation with uGGT. The decline in the number of renal epithelial cells (kidney cells and pelvis cells) observed in the urine at later time points suggested resolution of kidney injury in most of the animals. The presence of casts is influenced by urine concentration. Casts are degraded more rapidly in dilute urine which underestimates the actual number. In general, there was a higher frequency of animals with cylindruria when the urine was more concentrated; however, a significant correlation existed only for cellular casts $(\mathrm{P}=-0.09)$.

\section{CONCLUSION}

All of the female dogs with pyometra in this study presented with glomerular injury, tubular injury, or both. The injury to the kidneys was transient in most animals; however, it persisted up to 60 days post-surgery in some cases, emphasizing the importance of continued monitoring of kidney function. Increased uGGT, UPCR, and serum phosphorus levels were earlier markers of kidney injury than increased serum creatinine levels, and should be used to evaluate female dogs with pyometra for possible acute kidney failure.

\section{RESEARCH ETHICS COMMITTEE AND BIOSAFETY}

This study was approved by the Ethics Committee on Animal Research (CEUA/UFMG), protocol 198/2011.

\section{ACKNOWLEDGMENTS}

We would like to thank Conselho Nacional de Desenvolvimento Científico e Tecnológico (CNPq) for funding this study and the Dean of Research of the Universidade Federal de Minas Gerais (UFMG) for funding the translation of this article.

\section{REFERENCES}

ALBUQUERQUE, M.C.S.C. Relação entre os sinais clínicos e os achados laboratoriais de hematologia e provas bioquímicas em cadelas com piometra. 2010. 91f. Dissertação (Mestrado em Medicina Veterinária) - Faculdade de Medicina Veterinária da Universidade Técnica de Lisboa. Lisboa.

CHEW, D.J. et al. Canine and feline nephrology and urology. 2.ed. St. Louis: Elsevier Saunders, 2011. 526p.

DE SCHEPPER, J. et al. Urinary $\gamma$-glutamyl transferase and the degree of renal dysfunction in 75 bitches with pyometra. Res Vet Sci, v.46, p.396-400, 1989.

EVANGELISTA, L.S.M. et al. Função renal em cadelas com piometra antes e após ovário salpingo histerectomia. Acta Vet Bras, v.4, n.3, p.153-161, 2010.

FINCO, D.R. Association of systemic hypertension with renal injury in dogs with induced renal failure. J Vet Intern Med, v.18, p.289-294, 2004.

FOSSUM, T.W. Cirurgia dos sistemas reprodutivo e genital. In: Cirurgia de pequenos animais. 3.ed. Rio de Janeiro: Elsevier, 2008. P.702-774.

FREITAS, G.C. et al. Testes de avaliação de injúria renal precoce em cães e gatos. Semina: Ciênc Agrár, v.35, n.1, p.411-426, 2014.

GRAUER, G.F. Canine glomerulonephritis: new thoughts on proteinuria and treatment. J Small Anim Pract, v.46, p.469478, 2005. 
GRECO, D.S. et al. Urinary $\gamma$-glutamyl transpeptidase activity in dogs with gentamicin-induced nephrotoxicity. Am J Vet Res, v.46, n.11, p.2332-2335, 1985.

HARLEY, L.; LANGSTON, C. Proteinuria in dogs and cats. Can Vet J, v.53, n.6, p.631-638, 2012.

HEIENE, R. et al. Renal histomorphology in dogs with pyometra and control dogs, and long term clinical outcome with respect to signs of kidney disease. Acta Vet Scand, v.49, n.13, p.1-9, 2007.

HEIENE, R.et al. Calculation of urinary enzyme excretion, with renal structure and function in dogs with pyometra. Res Vet Sci, v.70, p.129-137, 2001

MADDENS, B. et al. Evaluation of kidney injury in dogs with pyometra based on proteinuria, renal histomorphology, and urinary biomarkers. J Vet Intern Med, v.25, p.1075-1083, 2011.

MASTROCINQUE, S. Anestesia em ginecologia e obstetrícia. In: FANTONI, D.T.; CORTOPASSI, S.R.G. Anestesia em cães e gatos. São Paulo: Roca, 2002. Cap.23, p.231-238.

MIRA, A. Firocoxib (Previcox $\left.{ }^{\circledR}\right)$ no tratamento da síndrome da resposta inflamatória sistêmica em cadelas com piometra. 2010. 134f. Dissertação (Mestrado em Ciências Veterinárias) Universidade Federal do Paraná, Curitiba, PR.

NABITY, M.B. Urine protein and microalbuminuria. In: BARTGES, J.; POLZIN, D.J. Nephrology and urology of small animals. West Sussex: Wiley-Blackwell, 2011. Cap.8, p.58-61.

OLIVEIRA, K.S. Complexo hiperplasia endometrial cística. Acta Sci Vet, v.35, supl.2, p.s270-s272, 2007.

ROCHA, D.F.; VEADO, J.C.C Gamaglutamil transpeptidase (GGT) urinária, proteína urinária e fósforo sérico no diagnóstico precoce da insuficiência renal aguda em cães. In: CONGRESSO MINEIRO DA ANCLIVEPA, 2005, Belo Horizonte, MG. Anais... Belo Horizonte: ANCLIVEPA, 2005.

ROSA, D.B.S.K. et al. Glomerulonefropatia em injúria renal aguda e doença renal crônica - Parte III. Medvep Pequenos Animais e Animais de Estimação, v.44, supl.44, p.120-127, 2016.

SANTOS, K.K.F. Guia prático de nefrologia em cães e gatos. Rio de Janeiro: L.F. Livros, 2014. 272p.

STEPIEN, R.L.; ELLIOTT, J. Measurement of blood pressure. In: ELLIOTT, J; GRAUER, G.F. BSAVA manual of canine and feline nephrology and urology. 2.ed. Gloucester: British Small Animal Veterinary Association, 2007. p.178-191.

STOCKHAM, S.L.; SCOTT, M.A. Sistema urinário. In: Fundamentos de patologia clínica veterinária. 2.ed. Rio de Janeiro: Guanabara Koogan, 2011. p.342-411.

STONE, E.A. et al. Renal dysfunction in dogs with pyometra. J Am Vet Med Assoc, v.193, n.4, p.457-464, 1988.

VERSTEGEN, J. et al. Mucometra, cystic endometrial hyperplasia, and pyometra in the bitch: advances in treatment and assessment of future reproductive success. Theriogenol., v.70, p.364-374, 2008.

YU, I.J. Hematological and serum chemical characteristics of open-cervix and closed-cervix pyometra in bitches. J Anim Vet Adv, v.11, n.19, p.3658-3661, 2012.

ZARAGOZA, C. et al. Canine pyometra: a study of the urinary proteins by SDS-PAGE and Western blot. Theriogenol., v.61, p.1259-1272, 2004 